\title{
Rejuvenation of the Former Coal Mining Industry Area into a Heritage Site: A Solution to Overcome the Threat of Environmental and Social Problems
}

\author{
Delmira Syafrini $^{\mathrm{a}}$, Muhamad Fadhil Nurdin ${ }^{\mathrm{b}}$, Yogi Suprayogi Sugandi ${ }^{\mathrm{c}}$, Alfan Miko ${ }^{\mathrm{d}}$ \\ ${ }^{a}$ Department of Sociology, Faculty of Social Sciences, Universitas Negeri Padang, Padang, Indonesia \\ E-mail: syafrinidelmira@gmail.com \\ ${ }^{b}$ Department of Sociology, Faculty of Social and Political Sciences, Universitas Padjadjaran, Bandung, Indonesia \\ E-mail: psrlayung@yahoo.com \\ ${ }^{c}$ Department of Public Administration, Faculty of Social and Political Sciences, Universitas Padjadjaran, Bandung, Indonesia \\ E-mail: yogi.suprayogi@unpad.ac.id \\ ${ }^{d}$ Department of Sociology, Faculty of Social and Political Sciences, Universitas Andalas, Padang, Indonesia \\ E-mail: alfanmiko@soc.unand.ac.id
}

\begin{abstract}
The defunct coal mining industries have turned into slums, and abandoned by its inhabitants, thereby leaving behind a damaged environment with complex social problems. However, in Sawahlunto, Indonesia, abandoned and damaged coal mining industries can be rejuvenated into productive areas that are an environmentally friendly and exciting place to visit. Therefore, this research aims to analyze processes and the various techniques used to rejuvenate the abandoned coal mining area located at Sawahlunto, Indonesia, into an industrial heritage site. The process also acts as a solution to overcoming the environmental threat and social problems associated with the defunct coal mining industry area. This study used qualitative research methods, with data primarily collected through observations and in-depth interviews. Furthermore, in-depth interviews were conducted on various city stakeholders with adequate knowledge of the process and its impact on the rejuvenation of the former coal mining industry area in Sawahlunto. The results showed that the rejuvenation of the former coal mining industry as an industrial heritage site has proven to be the right strategy to generate productivity and restore hope to local communities living around the area. The rejuvenation of the former mining area was also the primary factor driving the city's regeneration. It helped ensure that the area is not turned into slums or deserted by the inhabitants. Currently, Sawahlunto has grown into a highly-valued coal mining heritage city in Indonesia and has been declared a UNESCO World Heritage Sites.
\end{abstract}

Keywords- post coal mining industry; environmental and social problems; ghost town; rejuvenation of mining area; coal mining heritage; regional productivity

\section{INTRODUCTION}

The defunct of the mining industry leads to adverse environmental and social health problems in the surrounding communities [1]. In various countries, several large and well-known mining areas are either neglected or damaged. It also marks the end of the city's life because the inhabitants tend to abandon such regions. After all, it is considered unreliable as well as unable to sustain their lives [2], [3], and this led the area is dubbed a ghost town [4].

Some of these abandoned areas have successfully overcome the problem of neglect and extinction by rejuvenation, thereby regaining its productivity [2], [5]-[7].
Therefore, the strategy to rejuvenate the abandoned mining industry into a heritage site and tourism object was implemented.

Sawahlunto is one of the former coal mining cities that were successfully rejuvenated into a mining heritage site, a tourist attraction, located in West Sumatra Province, Indonesia. This city has been the largest coal mining city in Southeast Asia since the 20th century; however, in 1998, there was a depletion of coal reserves due to excessive exploitation, and this led to a halt. The cessation of mining activities in the city was disastrous, causing loss of livelihood and dangerous areas. Many of the former mining excavations and old buildings were abandoned, converted 
into slums, and haunted locations. This condition is further exacerbated by the residents' high rate of migration because they believed that the city lacked life expectancy. Therefore, from 1998 to 2001 was a difficult period because Sawahlunto threatened as a ghost town [8].

Most cities in various countries that rely on the mining sector are also vulnerable to this incident. Some are completely abandoned by their inhabitants and are presently labeled as dead. However, an interesting occurrence happened in Sawahlunto; various relics that were initially considered as ecological damage were recycled to produce an object of heritage. Presently, tourism has been developed in Sawahlunto, and it utilizes various primary resources such as legacies from the mining industries. The mine pit that was once damaged and inundated with dirty water is currently converted into a tourism lake. An arid mining area is either reformed into a fruit garden or a family arena, while old buildings are converted into cultural heritage edifices. Several museums were established to complement the series of events behind various mining equipment in the Dutch colonial era. Sawahlunto was transformed into a recognized tourism city in Indonesia, as well as declared a world heritage.

Based on the background of this research, this paper aims to discuss the rejuvenation processes carried out on the former coal mining industry in Sawahlunto to transform it into a visited coal mining heritage site, thereby increasing the productivity of an area that had initially lost its function.

This study is essential due, considering that Sawahlunto can be an example of a mining town in a developing country that can overcome the threat of a city declined after the end of the coal mining industry, not only solving environmental and social problems but also arousing the productivity of regions that have experienced a decrease. The same case does not only occur in Sawahlunto, but the decline in mining areas is vulnerable to be experienced by many mining areas in the world.

Several previous studies have reported the impact of these activities on the environment, as well as the successful development of tourism in areas formerly utilized for mining purposes, which has been stated to increase productivity [1], [5]-[7], [9]-[12]. Furthermore, those researches focused on aspects of economic sustainability [9], identity issues [10], development of mining heritage tourism [1], [5]-[7], [11], as well as the impact of mining activities on the environment [12]. However, the examination of human creativity to respond to the challenges that arise after the end of the mining industry is still limited for rejuvenating the area and the sustainability lives of people around the former mining area. Therefore, this needs to be analyzed because the shutdown of the mining industry is not only concerning technology on the environment. Instead, it is also closely related to the sustainability of social life in the surrounding communities. Therefore, this study also contributes to the original novelty, which was not discussed in previous studies.

\section{MATERIALS AND METHOD}

This study utilized the qualitative research method, with data collected through observation techniques and in-depth interviews. The obtained data were analyzed because they were considered capable of comprehensively disclosing the process involved in rejuvenating the ex-mining area in Sawahlunto. It is also suitable for getting an in-depth knowledge of the phenomenon to state the meanings, actions, values, experiences, interactions, and behavioral patterns of the object studied [13].

This study was conducted from May to December 2018. The research analysts lived and interacted with the local communities around the Sawahlunto coal mine area to observe its current condition. Observations were also carried out at the various mining sites such as mine pits, which have been converted into mining lakes, family recreational parks, mining heritage museums, and cultural reserves closely related to coal mining activities in the past.

Interviews were carried out on 30 male and female informants for 30 to 90 minutes. These informants were from various stakeholders, namely policymakers, indigenes, and visitors, aged between 17 to 65 years. A semi-structured interview was applied to explore information concerning the rejuvenation of the former coal mining area, its condition before and after the process, its impact on environmental preservation and sustainability, as well as the management of the mining heritage carried out by stakeholders in Sawahlunto community.

Meanwhile, secondary data was obtained from various documents, such as old archives, photos, videos, books, reports, and newspapers that provide information concerning the history of Sawahlunto and its present condition as a coal mining heritage city. A combination of these three data collection techniques strengthens the validity of the results from this research, which were further modified, and analyzed using relevant literature.

\section{RESULTS AND DISCUSSION}

\section{A. The Impact of the End of Coal Mining Industry in Sawahlunto}

Since 1891, Sawahlunto is one of the leading coal mining cities in Indonesia. Its mining industry is recognized as the most reliable in Southeast Asia due to its accomplishment in supplying coal to various countries in the world. Since its inception by the Dutch Colonial government, the community's social, economic, and cultural life is deeply embedded in the industry's activities. This sector greatly influenced peoples' livelihoods and provided basic amenities such as water, electricity, transportation, and residences. Coal is also the largest source of income in the region, generating approximately two and a half billion rupiahs per year, and a minimum mine production of $1,059,138.2$ tons [8].

In 1998, the first impact of the monetary crisis in Indonesia and the community's reformation was experienced. The regional autonomy accompanied this in 1999, which relieved the people of Sawahlunto City at that time. Reform and regional autonomy are interpreted as a form of freedom. For hundreds of years, they believed that the Netherlands and the state had charge of the coal mines. Therefore, they benefitted from their hard work by becoming doers and connoisseurs of mining products rather than spectators and workers. 
The consequence of that freedom led to the emergence of several illegal mines by unauthorized people. The development of several illegal mines in Sawahlunto transferred the state dominance in Ombilin coal mining to the indigenes, causing a change in their lives at that time. At least the community was able to benefit from the money generated from coal [14].

On the contrary, the emergence and development of community mining in Sawahlunto City had a positive impact on the economy. However, this led to the beginning of the disaster with the Coal Mining Company, referred to as PTBA-UPO. PTBA-UPO, with an area of approximately 15,000 hectares and a leading mine for over a century, experienced significant losses. It became non-functional due to a deficit in the company's finances. Five hundred billion loss was declared, which led to the decision to cease production and official closure of the company in 2003.

The indigenes of Sawahlunto had trouble from 1998 to 2003. The collapse of the mining industry caused severe problems in the sustainability of the town. The termination of \pm 1300 employments accompanied this decision, and this means that 1300 persons lost their jobs and other sources of livelihoods, such as trade, services, as well as agriculture. Consequently, people started to abandon the city, which became quiet. Furthermore, a decline was observed in the total population. Within a period of 7 years from 1995 to 2002, a drastic reduction of 3557 people or $6.46 \%$ was recorded at the time [15].

Besides the decreasing population, other phenomena also aggravate life in the city. The poverty rate increased from 1996 to 1999 . In 1996 the number of poor people in the city was approximately $4.5 \%$ and accelerated to $14.9 \%$ of the total population in 1999 . Over the past three years, the poverty rate has risen by $10.4 \%$ [16]

The most severe crisis was experienced from 1998 to2003, the first to have ever occurred in the city's development history. The city also encountered environmental damages and social problems. The cessation of mining activities led to dilapidated buildings. Several excavated damaged mine pits were converted into puddles of rainwater that served as a breeding ground for mosquitoes and other harmful insects (Fig. 1).

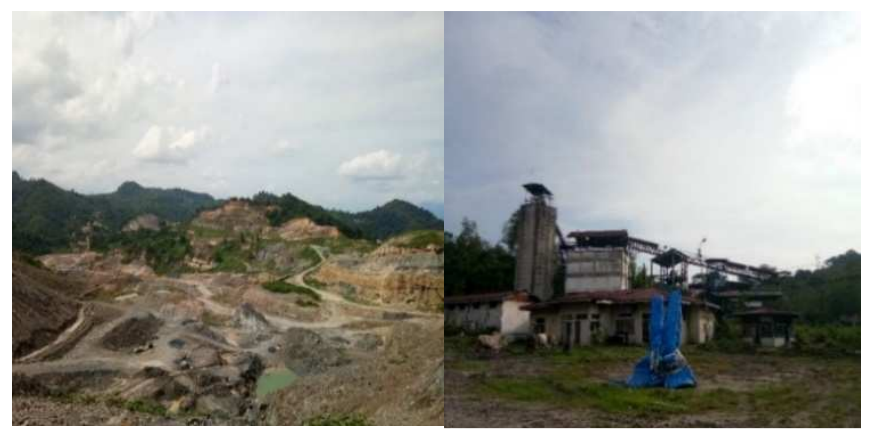

Fig. 1 Sawahlunto city coal former land and building

The threat of being a ghost town was imagined at that time. There needs to be a concrete step in rebuilding Sawahlunto City from the threat of damages and death. It was evident that coal was unable to sustain the life of the people, and continual mining further aggravated environmental conditions. It became the shadow of a dead city only remembered in history as a coal mining city that had once thrived and was destroyed by excessive exploitation.

The cessation of the mining sector harms the productivity of an area. Similar cases are also experienced in various countries. Furthermore, inappropriate mining practices have several negative impacts, such as environmental pollution, which led to damages in the ecosystems [12], and public health problems [17]. Nevertheless, coal mining remains one of the sectors that sustain the economic development of any community [18]. This means that the mining industry has two inseparable aspects.

On the contrary, long-term mining activities have a series of negative impacts on environmental sustainability and social life. This impact is increasingly apparent after the cessation of mining activities, which left various sites damaged. However, assuming its improperly managed, it turns into a dead and haunted area. Furthermore, when appropriately managed, it becomes an attractive place, thereby generating new economic opportunities for people around the area [19].

\section{B. Rejuvenation of the Former Mining Area: Efforts to Revive Regional Productivity}

Numerous mining industries in several countries often experience cases like the incident that occurred in Sawahlunto. Some of them were abandoned and referred to as a ghost town such as Bodie, California, Komalskop, and Namibia [20], [21]. Subsequently, some of them were rejuvenated into productive areas. Most of the abandoned areas which became ghost towns were converted to attractive sites, namely Gunkanjima Island Japan, Ravenswood, North Queensland, Australia, and Tombstone, Arizona USA [1], [5]. The strategy implemented to restore the productivity of these regions is by rejuvenating the former mining industry into a mining heritage site.

The past three decades witnessed the rejuvenation of the former mining area into a heritage site. Conversely, this is increasingly being applied in several cities that encountered the halt of mining industries. Because such areas are considered to have potentials that, when properly managed, are transformed into an attractive arena and improves the economy of the surrounding regions, thereby inciting its sustainability, as well as reviving the declining community activities, which occurred due to decreased productivity [2].

Rejuvenation is an effort to improve areas that have experienced environmental degradation due to mining activities to become productive. Various methods and techniques are used to rejuvenate these areas to revitalize those regions that have lost their productive functions. An effective means is to transform the former mine into a mining heritage tourism object. This re-management is also an aspect of the conservation efforts. Restoring sites damaged by mining activities involves the preservation of historical values [22]. It becomes undoubtedly interesting because, in addition to benefitting from nature, mining tourism also offers memorable knowledge that serves as an identity of the city while restoring the paralyzed social life. It also means the redevelopment of the industrial mining area, which originated from previous activities [2], [22]. 
Based on these principles, the former mining location is the primary resource that needs to rejuvenate into an attractive site. Also, recycling of mine sites is a form of conservation. This incident involves the conservation of physical locations or mining buildings and irreplaceable history [23], [24].

Following the creation of these attractions, Philip Feifan Xie further stated that some basic requirements need to be met in developing specific aspects of mining tourism, namely potentials/resources, adaptive reuse, supporting economic sectors, authentication, uniqueness, and an unprecedented identity of tourism, public perception, and stakeholders) [24].

It is essential to rejuvenate these defunct mining areas as a tourist attraction center, thereby enhancing the city's social and environmental problems [1] To achieve this, the old mining area needs to be revived and adequately maintained, with the erection of museums.

However, it is impossible to dismiss the reality of mining activities associated with its physical space since the visitors enjoy both the tourist attraction and the realities that occurred at such locations. Visitors tend to appreciate mining activities, such as entering a dark alley, observing the equipment used, and information concerning the miners. The uniqueness, authenticity, and experiences gained are also referred to as the sense of place, which is an essential aspect of the physical intervention of the city revitalization process [25]-[27]. However, it is not enough to generate beauty from the physical and historical aspects of the city. Furthermore, the sense of place is closely related to the local community's cultural factors, which are an essential aspect of the development of tourism [25].

The rejuvenation of mining heritage sites into tourists' attractions restores the productivity of the region. Some of the former mining cities that were labeled 'ghost towns' have been able to revive their post-mining glory by developing mining heritage tourism [1], [20]-[22].

According to Bruce Preadeaux and Dallen J. Timothy, the mining industry is vulnerable to decline and neglect when there is a cessation of its activities and even tends to be an abandoned area when it is no longer a reliable source of economic support. However, the area regains its productivity by rejuvenating the former mining industry into a heritage tourism site.

It was also supported by Atsuko Hashimoto and David J. Telfer [1], which stated that the rejuvenated area with low productivity function offers new energy to the abandoned places.

\section{Rejuvenation of the Former Coal Mining Industry Area into a Mining Heritage Tourism Site in Sawahlunto}

The rejuvenation of the mining area into a coal mining heritage and tourism objects is also an option considered by Sawahlunto City stakeholders after the cessation of the mining industry. The city government and the indigenes reused the site as a tourism object for various purposes. Also, the productivity of the area was also revived in order to benefit and sustain the people.

Efforts to rejuvenate the area have been carried out since 2003, which started with a change in the vision of Sawahlunto, to transform it to a cultured mining tourism city in 2001. These efforts were realized through concrete actions such as building various tourism destinations and mining heritage sites in various locations that were formerly coal mines. Various relics of the mining industry that were initially environmentally damage and posed as threats to the preservation of the city became the leading resource for the development of the tourism site.

Rejuvenation efforts are carried out on all aspects of the former location, both the natural landscapes around the mine sites, such as excavations and legacies, e.g., cultural heritage. The heritage involves buildings, artifacts or objects, equipment used in mining activities, history and stories of the workers, and traditions. Rejuvenation transforms the function of the former mining area and increases productivity in the abandoned site. Consequently, damaged, deserted, and haunted places are re-visited.

TABLE I

The Changes Of Function CoAl Mining Area After The REJUVENATION

\begin{tabular}{|c|c|c|c|}
\hline $\begin{array}{l}\text { Coal Mining } \\
\text { Activities Legacy }\end{array}$ & Rejuvenation & $\begin{array}{l}\text { Current Area } \\
\text { Function }\end{array}$ & Amount \\
\hline \multicolumn{4}{|c|}{ Natural Coal Mining Legacy } \\
\hline \multirow[t]{2}{*}{ Coal mining hole } & \multirow{2}{*}{$\begin{array}{l}\text { Coal mining } \\
\text { lake }\end{array}$} & Kandi lake & \multirow[t]{2}{*}{2} \\
\hline & & Blue lake & \\
\hline $\begin{array}{l}\text { Swimming pool of } \\
\text { the Dutch Colonial } \\
\text { Mining Company }\end{array}$ & \multirow[t]{5}{*}{$\begin{array}{l}\text { Family } \\
\text { recreation }\end{array}$} & Waterboom & 1 \\
\hline \multirow[t]{2}{*}{$\begin{array}{l}\text { The natural } \\
\text { environment around } \\
\text { the mining area }\end{array}$} & & $\begin{array}{l}\text { Kandi Wildlife } \\
\text { Park for family } \\
\text { tourism }\end{array}$ & \multirow[t]{2}{*}{2} \\
\hline & & Fruit Garden & \\
\hline \multirow{2}{*}{$\begin{array}{l}\text { The view of the } \\
\text { former Mining City } \\
\text { is seen from the Hills }\end{array}$} & & Puncak Cemara & \multirow[t]{2}{*}{2} \\
\hline & & Puncak Polan & \\
\hline \multicolumn{4}{|c|}{ Cultural Coal Mining Legacy } \\
\hline \multirow{4}{*}{$\begin{array}{l}\text { Mining industry } \\
\text { public kitchen } \\
\text { building, Railway } \\
\text { Station, and Mining } \\
\text { workers meeting } \\
\text { building in Soero } \\
\text { Mining Hole } \\
\text { Complex } \\
\text { Equipment used for } \\
\text { mining activities } \\
\text { History and the story } \\
\text { behind mining } \\
\text { workers' activities }\end{array}$} & \multirow[t]{4}{*}{$\begin{array}{l}\text { Coal mining } \\
\text { heritage } \\
\text { museum }\end{array}$} & $\begin{array}{l}\text { Goedang } \\
\text { Ransoem } \\
\text { Museum }\end{array}$ & \multirow[t]{4}{*}{3} \\
\hline & & $\begin{array}{l}\text { Railway } \\
\text { Museum }\end{array}$ & \\
\hline & & $\begin{array}{l}\text { Mbah Soero } \\
\text { Mining Hole } \\
\text { Museum }\end{array}$ & \\
\hline & & & \\
\hline $\begin{array}{l}\text { Former mining } \\
\text { industry building, } \\
\text { home of mining } \\
\text { officials and workers }\end{array}$ & $\begin{array}{l}\text { Cultural } \\
\text { heritage } \\
\text { buildings }\end{array}$ & $\begin{array}{l}\text { Coal mining } \\
\text { heritage building }\end{array}$ & 64 \\
\hline $\begin{array}{l}\text { Dutch graveyard } \\
\text { (Kerkhof) }\end{array}$ & $\begin{array}{l}\text { Coal mining } \\
\text { heritage site }\end{array}$ & $\begin{array}{l}\text { Dutch tomb } \\
\text { cultural heritage }\end{array}$ & 1 \\
\hline
\end{tabular}

Ex-mining pits that were flooded with water and became sources of disease are converted into mining lakes currently referred to as the Kandi Tourism Area. In 2001 this area was an abandoned site owned by the Coal Mining Company that was no longer productive, and it was also part of the Sawahlunto region, which was ecologically damaged due to mining activities. This community is considered as a haunted place. People dared touch or even passed through it because of the large pool of water surrounded by forests and lack of 
accessibility. The Kandi tourism area is referred to as a haunted place by the public. However, in 2003 the area was conserved by converting it into an artificial lake, equipped with a game arena, zoo, garden, and camping ground under the concept of family recreation, as shown in Fig. 2.

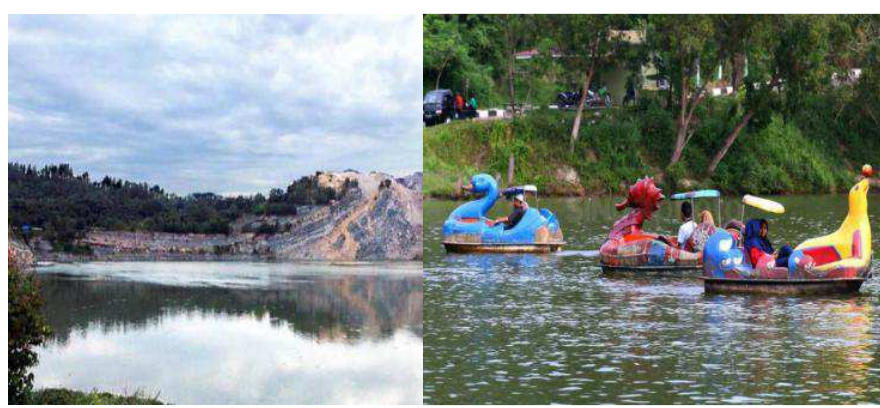

Fig. 2 Kandi tourism complex after its conservation

The Sawahlunto City Government also explores various legacies from past mining activities and converted them into family attractions to attract visitors. This case is like the conservation of a former swimming pool to Waterboom Tourism by the Dutch officials from the late 19th to the mid20th century. The Puncak Cemara tourist attraction also complemented this sight. It is a park built in the City hills in order to view the natural landscape and architecture of the Old Dutch mining town from the hill (Fig. 3).

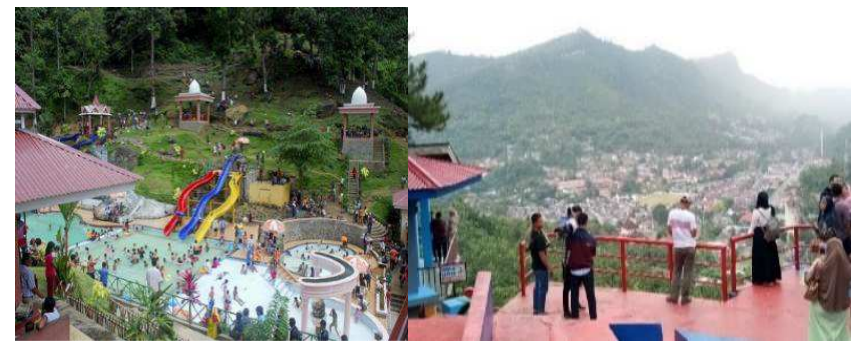

Fig. 3 Waterboom and Puncak Cemara recreational tourism in Sawahlunto

In addition to conserving ex-mining land as a natural tourist attraction and recreation, revitalization efforts are also carried out on dilapidated buildings linked to the history of mining during the Dutch Colonialism. These buildings are revitalized into a cultural reserve and museum. Approximately 64 cultural heritage sites and the former industrial buildings, as well as residential homes for officials and employees, have been linked to mining activities in Sawahlunto since the Dutch Colonialism. However, 3 of the building were revitalized as mining museums.

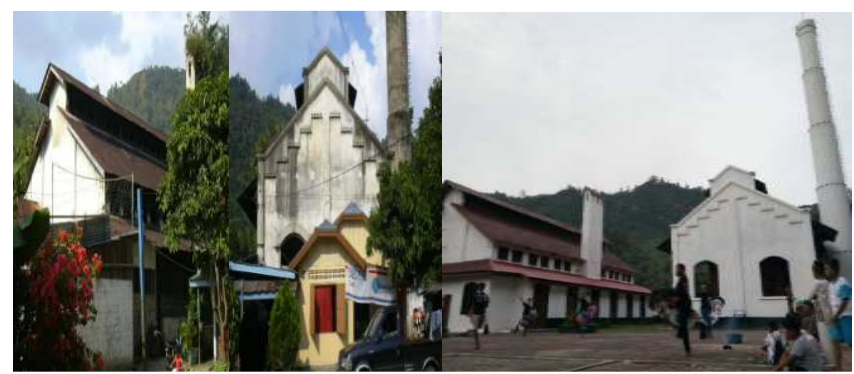

Fig. 4 The changing of a former mining company public kitchen into a Goedang Ransoem museum
Firstly, the Goedang Ransoem Museum is set up in an old building that was formerly used as a public kitchen by the coal mining company to produce staple food for miners. The museum contains 6000 collections of utensils that were used during the Dutch colonial period, as shown in Fig. 4.

Second, the Mbah Soero Mining Hole Museum was erected above the mine pit, which consists of a tunnel that was approximately $185 \mathrm{~m}$ long. This mining pit also constitutes an essential aspect of history, which marks the miners' activities that were mostly prisoners all over Indonesia. They need to serve their jail terms, which involve hard labor without pay, and they were to remain chained with exploited feet. The locales referred to them as 'chain people.' The stories behind the struggles of this chain are now being brought back to the museum. The purpose is to remind the public about the history of the Sawahlunto ancestors, as shown in Fig. 5.

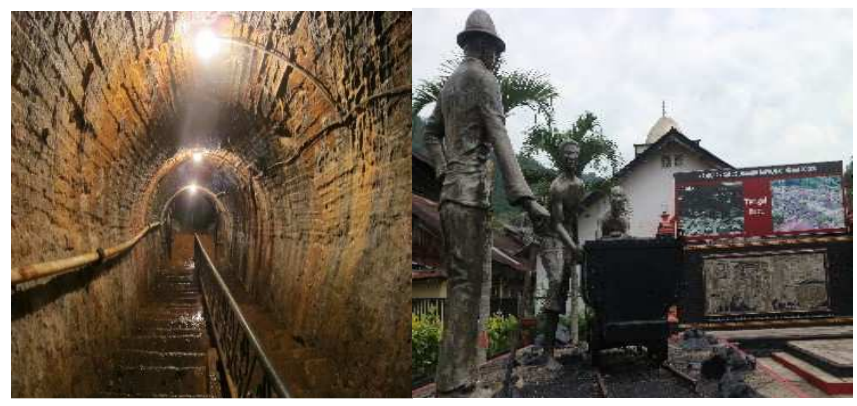

Fig. 5 Recycling Soero Hole into the Mbah Soero mining hole museum

Third, the Railway Museum was established in a building formerly used as a coal transportation train station, transiting from Sawahlunto to the port to export coal abroad. The building, which was initially used for coal transportation activities for relatively 100 years, becomes an abandoned space due to a lack of extended functions. The train station and its equipment meant a lot to the people of Sawahlunto City for over a century. The station was revitalized into a railroad museum, thereby exhibiting approximately 106 equipment used for coal transportation, as shown in Fig. 6.

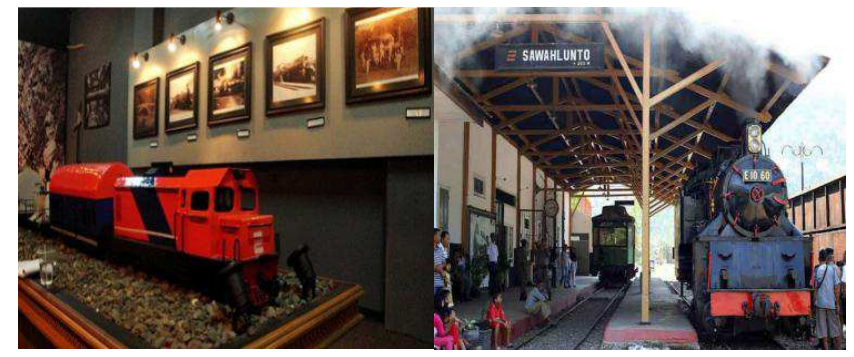

Fig. 6 Changing functions of the railway station into the railway museum

The revitalization of the former mining industries into three museums is an effort to revive historic buildings that contain memories from the past. These buildings were initially dilapidated because they have been abandoned for a long time. Presently these buildings are productive and tend to reveal the past glory of coal mining, which is the pride of the Sawahlunto community. Rejuvenation of the former mining industrial area resuscitated the Sawahlunto community. The location, which was initially considered a threat to the environment and the livelihoods of urban 
communities, became a significant resource that is reckoned in Indonesia and recognized worldwide. The various former mining sites were transformed into mining heritage areas within ten years. The process of development and rejuvenation in Sawahlunto is shown in Fig. 7.

The chart states the processes involved in developing a former mining industrial area to a mining heritage site. After the mining industry's cessation, there were two possible directives for the rejuvenation of the region. Firstly, it becomes an abandoned and damaged slum, assuming it is left unattended to and neglected by the city stakeholders. Secondly, it is revitalized into a productive area, based on the condition that the rejuvenation of the former mining industry location becomes valuable and attractive. Therefore, the city stakeholders decided to rejuvenate the former mine's various relics into a heritage site and tourism object.

This process is divided into two, namely the rejuvenation of locations into natural mining attractions and the management of sites into cultural heritage. The natural landscape includes former mining pits and areas around the mine excavation, converted into a mine lake, and a recreational park equipped with children's playground. The cultural heritage includes buildings of the former mining industry, mining equipment, history, and stories associated with mining activities and various traditions formed due to social interaction with the mining community. It is further enshrined in mining heritage sites, such as museums, cultural reserves, and multiple attractions in festivals or carnivals that bring back memories of mining activities to the local people and visitors.

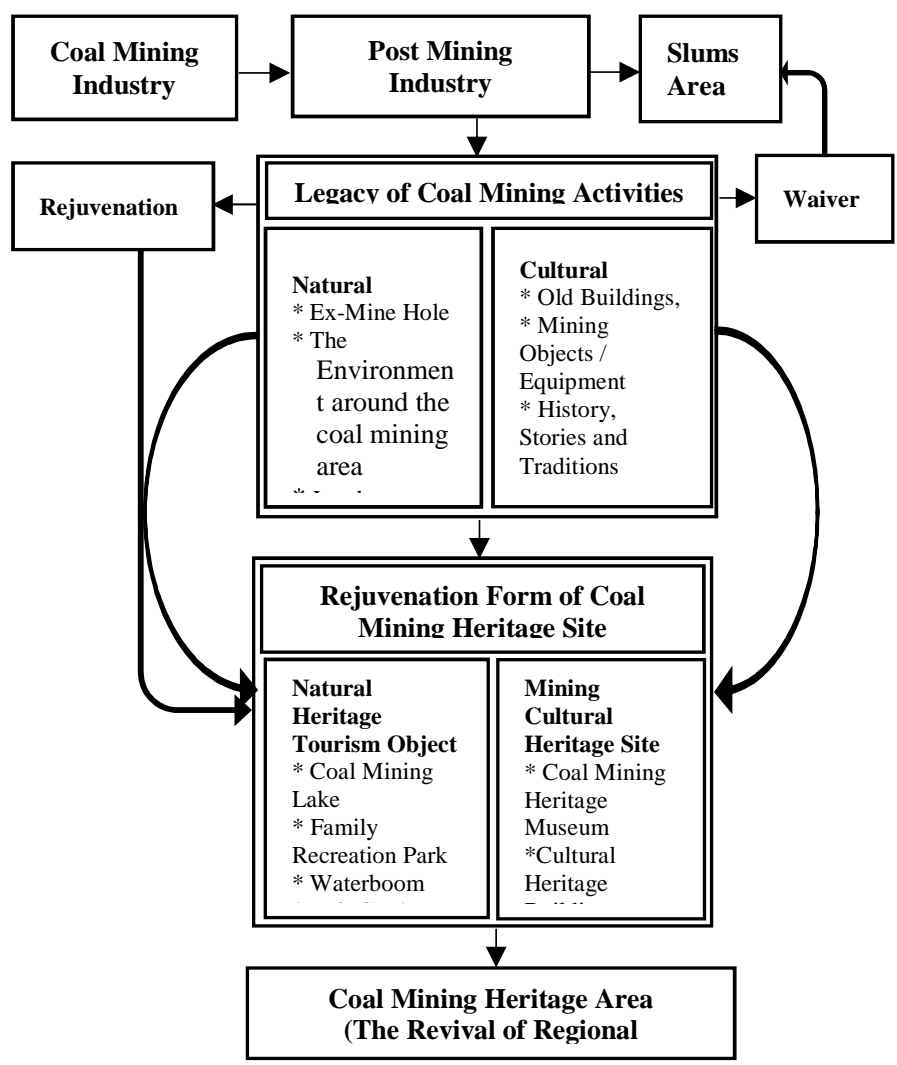

Fig. 7 Flowchart of development of the former area of the coal mining industry become a heritage site of coal mining in Sawahlunto
Re-utilization of the former mine site as a tourist attraction in Sawahlunto is reported to revive the productivity of the area simultaneously. It also protects the city from the threat of environmental damage. Presently, it is having been transformed into a comfortable and fascinating place to visit. The success of the rejuvenation is evident in the increased number of visits on a yearly. However, in 2004 approximately 14,425 visitors, were reported while in 2018 , the number of visits was relatively 733.721 visitors [28].

The success of this development is also evident in the revival of Sawahlunto from the slump. The city that was initially labeled a ghost town was presently one of the calculated tourist cities in Indonesia. The history of coal mining since the Colonialism era has become a high-value heritage, which made it possible for Sawahlunto to be recognized as one of the world heritages by UNESCO on the $9^{\text {th }}$ of July, 2019.

Many visits to the city, the resurgence of ex-mining land productivity, and the establishment of Sawahlunto comprises a world heritage. It is evidence that the rejuvenation of the former mining area is an alternative solution to overcome various threats and problems that arise after the halt of the mining industry in a field. It is also a new source of livelihoods for the people residing around the mining area, thereby automatically reducing social problems, such as poverty, population, unemployment, and crime.

The research analysts in several countries that have suffered similar incidents are interested in rejuvenating the area into a site for mining heritage and tourism objects. Hashimoto Tefler reported that Japan's Gunkanjima Island needs to rejuvenate after being abandoned and dubbed a ghost island after the cessation of mining activities on the island [1]. Conversely, Bruce Preadeaux, and Dallen J. Timothy [5], stated that tourism is an effective way to rejuvenate mining areas that have lost their productive functions. Similar research was conducted by Conlin Joliffe [2], which stated that the mining industry does harm the environment. Instead, it leaves a legacy that needs to be revitalized into an attractive and valuable selling location.

Various locations and buildings of the former mining industry are considered valuable. Also, it is stored with the history and memories of various past related activities. [29] In terms of sustainability, it boosts the economy of the surrounding community [30], and in some cases, it is the beginning of the community's social and cultural life. This means that the mining industry also relates to the identity of the local community [10]. Therefore, disregarding the various relics of the former mine implies ignoring history, which is the pride and identity of the present society. However, when various former mining sites are managed into a legacy that is frequently visited by the local people and migrants, it protects the environment from the threat of damages. It preserves the historical values relating to such activities that tend to be passed down to the next generation.

Re-management of the location into an industrial heritage site is the appropriate strategy to generate the productivity of a city labeled as dead, as is the case in Sawahlunto, Indonesia. Various former mining sites are driving forces for the city's sustainability to curb its threat to the environment and social life. Presently, Sawahlunto is developing a mining 
heritage city that is visited and recognized, both on a local, national, and global scale.

\section{IV.CONCLUSION}

The rejuvenation of the former coal mining area into a mine heritage site and tourist attraction is a practical approach for the sustainability of the region. Also, this strategy restores the abandoned area's productivity and prevents it from being labeled a dead city. Sawahlunto was transformed from a city that was almost dead to a tourist destination. Presently, Sawahlunto is recognized by UNESCO as one of the world's coal mining heritage. This recognition shows that the mining industry does not always damage, pollute the environment, and become extinct. However, it also leaves a variety of inheritance re-managed as the leading resource for the sustainability of life around the former mining area.

\section{REFERENCES}

[1] A. Hashimoto and D. J. Telfer, "Transformation of Gunkanjima (Battleship Island): from a Coalmine Island to a Modern Industrial Heritage Tourism Site in Japan," J. Herit. Tour., vol. 12, no. 2, pp. 107-124, 2017.

[2] M. V Conlin and L. Jolliffe, Mining Heritage and Tourism: A Global Synthesia. USA and Canada: Routledge, 2010

[3] R. Summerby-Murray, "Interpreting deindustrialised landscapes of Atlantic Canada: memory and industrial heritage in Sackville, New Brunswick," Can. Geogr. Can., vol. 46, no. 1, pp. 48-62, 2002.

[4] P. F. Xie, "Developing industrial heritage tourism: A case study of the proposed jeep museum in Toledo, Ohio," Tour. Manag., vol. 27, no. 6, pp. 1321-1330, 2006.

[5] B. Prideaux and D. J. Timothy, "From Mining Boom Towns To Tourist Haunts: The Ghost Town Life Cycle," in Mining Heritage and Tourism, M. V Conlin and L. Jolliffe, Eds. Newyork: Routledge, 2011, pp. 227-238.

[6] M. Pretes, "Touring Mines and Mining Tourists," vol. 29, no. 2, pp. 439-456, 2002.

[7] G. Steel, "Mining and Tourism," Lat. Am. Perspect., vol. 40, no. 2, pp. 237-249, 2013.

[8] A. Asoka, W. Samry, Z. Zubir, Zulqayyim, and Y. Saputra, Sawahlunto: Dulu, Kini dan Esok. Padang: Minangkabau Press, 2016.

[9] D. Cole, "Exploring the sustainability of mining heritage tourism," $J$. Sustain. Tour., vol. 12, no. 6, pp. 480-494, 2004.

[10] E. R. Ballesteros and M. H. Ramírez, "Identity and community Reflections on the development of mining heritage tourism in Southern Spain,” Tour. Manag., vol. 28, no. 3, pp. 677-687, 2007.

[11] M. Kruczek and Z. Kruczek, "Post-industrial tourism as a means to revitalize the environment of the former oil basin in the polish Carpathian mountains," Polish J. Environ. Stud., vol. 25, no. 2, pp. 895-902, 2016.
[12] Z. U. and M. S. I. Harun-Or-Rashid, Md. Sanower Hossain, "Environmental Impact of Coal Mining: A Case Study on the Barapukuria Department of Environmental Science and Resource Management, Faculty of Life Science," Middle-East J. Sci. Res., vol. 21, no. 1, pp. 268-274, 2014.

[13] N. K. Denzin and Y. S. Lincoln, Handbook of Qualitaive Research. Yogyakarta: Pustaka Pelajar, 2009.

[14] Z. Zubir and Zulqayyim, "Rontoknya Dominasi Negara di Tambang Batu Bara Ombilin Sawahlunto," Mamangan, vol. 1, no. 2, pp. 1526, 2014.

[15] BPS Kota Sawahlunto, "Sawahlunto Dalam Angka," Sawahlunto, 2016.

[16] BAPPEDA Kota Sawahlunto, "Profil Daerah Kota Sawahlunto Tahun 2017," Sawahlunto, 2017.

[17] S. M. Woolley, A. O. Youk, T. M. Bear, L. C. Balmert, E. O. Talbott, and J. M. Buchanich, "Impact of Coal Mining on Self-Rated Health among Appalachian Residents," J. Environ. Public Health, vol. 2015, 2015.

[18] M. R. Betz, M. D. Partridge, M. Farren, and L. Lobao, "Coal mining, economic development, and the natural resources curse," Energy Econ., vol. 50, pp. 105-116, 2015.

[19] J. Harfst, "Utilising the past: Valorizing post-mining potential in Central Europe," Extr. Ind. Soc., vol. 2, no. 2, pp. 217-224, 2015.

[20] D. Delyser, "Authenticity on the Ground: Engaging the Past in a California Ghost Town," Ann. Assoc. Am. Geogr., vol. 89, no. 4, pp. 602-632, 1999.

[21] N. Alexander, "Kolmanskop: An Industrial Heritage Resource or Only a Tourist Attraction," University of Cape Town, 2010.

[22] R. Summerby-Murray, "Interpreting Personalised Industrial Heritage in the Mining Towns of Cumberland County, Nova Scotia: Landscape Examples from Springhill and River Hebert," Urban Hist. Rev., vol. 35, no. 2, 2007.

[23] P. F. Xie, "A life cycle model of industrial heritage development," Ann. Tour. Res., vol. 55, no. 2015, pp. 141-154, 2015.

[24] P. F. Xie, "Developing Ethnic Tourism in a Diaspora Community: The Indonesian Village on Hainan Island, China," Asia Pacific J. Tour. Res., vol. 15, no. 3, pp. 37-41, 2010.

[25] S. Smith, "A sense of place: Place, culture, and tourism," Tour. Recreat. Res., vol. 40, no. 2, pp. 220-233, 2015.

[26] A. Campelo, R. Aitken, M. Thyne, and J. Gnoth, "Sense of Place: The Importance for Destination Branding," J. Travel Res., vol. 53, no. 2, pp. 154-166, 2014.

[27] M. Billig, "Sense of place in the neighborhood, in locations of urban revitalization," no. 2005, pp. 117-130, 2006.

[28] BPS Kota Sawahlunto, "Sawahlunto Dalam Angka," Sawahlunto, 2018.

[29] S. A. Smith and S. A. Smith, "Heritage tourism and New Western history: a narrative analysis of six Colorado museums," J. Herit. Tour., vol. 14, no. 1, pp. 1-18, 2018.

[30] S. R. Martin, "Reviewed Work (s): Mining Heritage and Tourism: A Global Synthesis (Routledge Advances in Tourism series) by Michael V. Conlin and Lee Jolliffe," Soc. Ind. Archeol., vol. 35, no. 1, pp. 23-26, 2017. 